\title{
Do Foreigners Cushion Native Jobs? The Case of European Regions in the 1990s
}

\author{
MASSIMILIANO TANI \\ University of New South Wales at the \\ Australian Defence Force Academy
}

\section{National Europe Centre Paper No. 67}

Paper presented to conference entitled

The Challenges of Immigration and Integration in the European

Union and Australia,

18-20 February 2003, University of Sydney

\footnotetext{
${ }^{1}$ I would like to thank Tim Hatton, Aki Kangasharju, and Tue Gorgens for valuable comments as well as participants to seminars at the Australian National University (RSSS Economics), the University of Canberra, and the EALE 2002. All errors are mine.
} 


\begin{abstract}
This paper investigates whether foreign labour cushions native employment during the phases of the economic cycle. The theoretical model, based on the work of Blanchard and Katz (1992), assumes that foreigners supply labour with a higher wage elasticity than natives. The empirical analysis, based on a panel of 161 European regions during 1988-1997, shows that following a labour demand shock the variability of native employment growth is lower the higher the proportion of foreign citizens in the local labour force. These results suggest that foreigners absorb some of the effects of the shock, shielding natives from its full impact.
\end{abstract}




\section{Introduction}

Understanding how local labour markets adjust following a shock to labour demand has become more relevant to the policymaker, particularly in an integrating world where barriers to labour mobility across countries are rapidly decreasing. One aspect within this topic is to study whether foreigners cushion native employment over the phases of the economic cycle. Foreigners can make a difference to a locale's response to a labour demand shock. For example, the additional labour supplied by immigrants could relieve pressure on native labour at times of economic expansion, whilst outmigrating foreigners during a recession could help maintain native job levels. This hypothesis is prima facie consistent with the picture presented in Figure 1, which shows the unemployment rates of native and foreigner citizens living in the South East of England during 1988-1997. Foreigners are divided into European Union citizens living in another member state ("intra-EU”), who since 1992 are free to move across member states, and non-EU citizens ("extra-EU”), whose international movements within the EU are still regulated by the destination country.

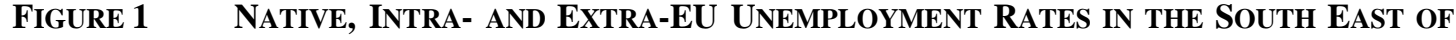 ENGLAND}

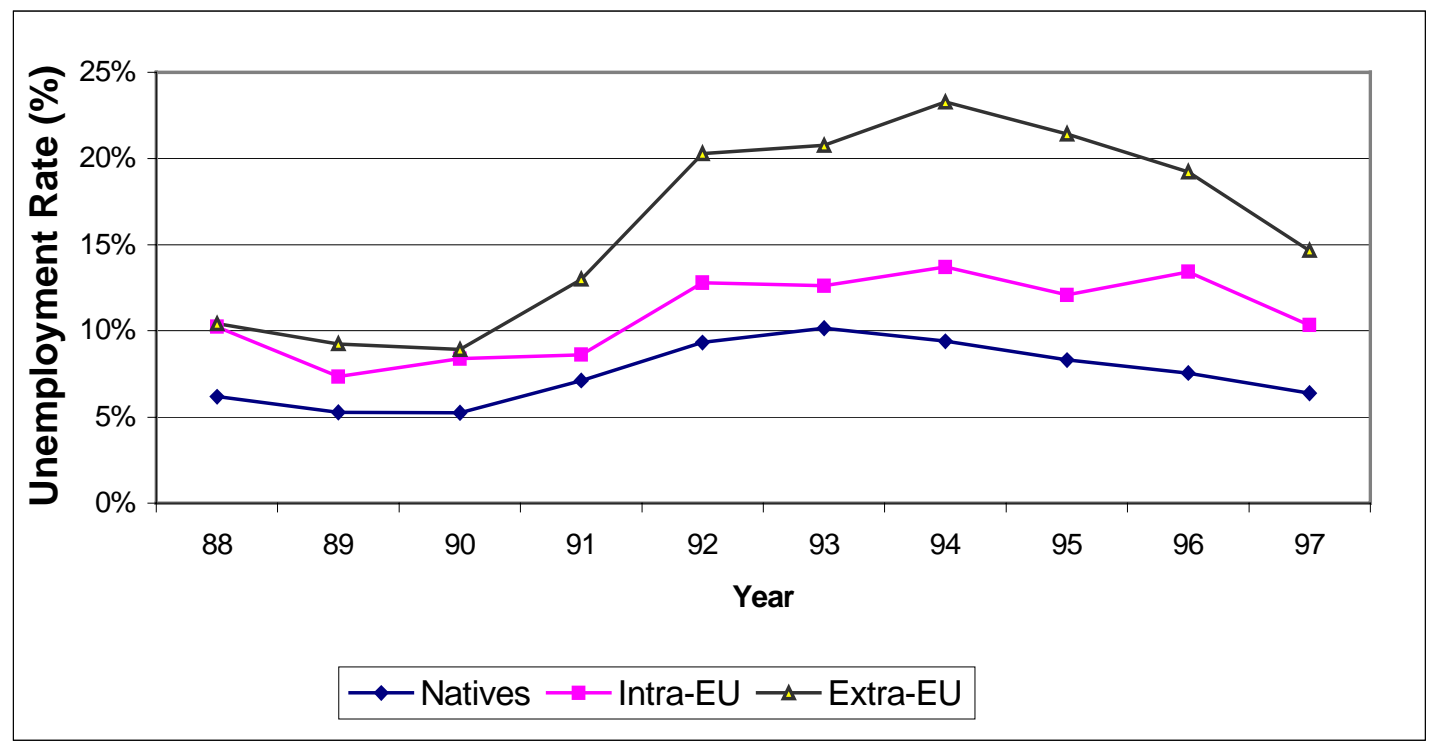

Source: Eurostat, Labour Force Survey, 1988-1997.

Although the period is short, Figure 1 shows that natives had a lower average unemployment rate and a lower absolute variability than both intra- and extra-EU citizens 2 Similar results arise for many other regions of the EU and on data aggregated at the national level (e.g. OECD 2000a,b). Do foreigners and

2 Although the skill composition of natives, intra- and extra-EU workers in the South East of England is comparable, Figure 1 shows that foreign unemployment grows faster than that of natives when the latter rises, and vice-versa, implying that employment is more variable among foreigners than natives. This conclusion applies to many other regions of the EU, and it is not new (e.g. OECD, 2000a,b). Using regional data across the whole EU the mean and standard deviation of unemployment by national group during 1988-1997 were as follows:

\begin{tabular}{cccc}
\hline Unemployment Rate by National Group & Mean & Standard Deviation & Nr Observations \\
\hline Natives & .104 & .059 & 1,519 \\
Intra-EU & .169 & .157 & 1,040 \\
Extra-EU & .254 & .164 & 1,255 \\
\hline
\end{tabular}


hence policies favouring international migration, affect the level or the variability of native employment?

This paper develops a theoretical model to address this question and presents some empirical results using European regional data from Eurostat's Labour Force Survey (LFS) for the period 1988-1997. The paper is organised as follows. Section 2 briefly reviews the reference literature whilst section 3 develops a theoretical model. Section 4 presents the statistical model and the data used in the empirical analysis, which is discussed in section 5. Section 6 concludes.

\section{Foreign Workers and Local Labour Markets: A Brief Literature Review}

The literature studying the effects of foreigners on native labour can be broadly divided in two. The first group of studies focuses on individuals and it analyses the impact of immigrants on wages and employment of native workers. These studies estimate functional models such as:

$$
\Delta \log \mathrm{w}_{\mathrm{jit}}=\Delta(\mathrm{F} / \mathrm{N})_{\mathrm{it}}+\Delta \text { control variables }
$$

where $w$ refers to the wages of native person $j$ in region $i$ at time $t, \mathrm{~F}$ and $\mathrm{N}$ indicate the number of foreigners and natives in the same region and year, respectively. Equation (1) is generally estimated as a pooled cross-section using data from censuses.

This literature finds small negative effects on wages and even smaller effects on employment (e.g. Simon, 1989; Borjas, 1994). There are only few empirical studies based on European data ${ }^{\text {G }}$ which tend to yield similar results (e.g. De New and Zimmermann, 1994; Dolado, Jimeno and Duce, 1996; Gavosto, Venturini and Villosio, 1999).

As these studies estimate average individual responses to an inflow of immigrants, they focus on specific aspects of a labour market's reaction (e.g. change in wages or employment levels) rather its overall response. However, they use the term migrant to mean either a foreign-born or an individual holding a different citizenship from that of the country of residence, which is the definition applied in this paper to purposely measure the labour market effect of international migrants.

In contrast, the second group of studies focuses on geographic areas and it often uses dynamic models to estimate the impulse response function of a local labour market following a labour demand shock. Many studies decompose the local labour markets' response into changes in local employment and participation rates, and in the working population 1 exploiting the identity:

$$
\Delta \log \mathrm{E}_{\mathrm{it}}=\Delta \log (\mathrm{E} / \mathrm{L})_{\mathrm{it}}+\Delta \log (\mathrm{L} / \mathrm{WP})_{\mathrm{it}}+\Delta \log \mathrm{WP}_{\mathrm{it}}
$$

\footnotetext{
3 In the context of European migration, the few existing empirical studies reflect partly a limitation in the availability of data (particularly EU-wide data with comparable definitions across member states) and partly the characteristics of European labour markets. Across the EU the wage structure tends to be more rigid as it is often bargained and set nationally by unions. As a result, the impact of foreign immigration on wages is a priori expected to be limited (e.g. Pischke and Velling, 1996).

${ }^{4}$ This is always true if the variables in (2) are measured in physical bodies (e.g. a rise in employment implies a change in the number of people). If the dependent variable is measured in efficiency units it is necessary to assume that the number of hours of labour supplied by each person is fixed.
} 
where $E$ is the number of employed in region $i$ at time $t, E / L$ is the employment rate, $L / W P$ is the participation rate and WP is the working population of the same region. Since most of the changes in the working population are due to in- and out-migration rather than demographics, $\Delta \log \mathrm{WP}$ is typically interpreted as a migration term.

US-based studies in this literature find that about two thirds of all jobs created in a locale go to immigrants (see Bartik, 1993 for a summary). European studies reach mixed conclusions. At the country level migration seems to be the principal adjustment mechanism through which a shock is absorbed (Spain: Jimeno and Bentolila, 1998; Sweden: Fredriksson, 1999). In contrast, at the EU level the shock seems to be mostly absorbed by changes in the participation rate and only later in time (3-4 years) by migration (Decressin and Fatas, 1995), though these results have been recently revisited (Tani, 2003).

Although these studies use the unit of measure applied in this paper (regions), they use the word migrant as a synonymous for newcomer with no distinction between a native from the same country or someone born abroad. As a result, domestic and international migrants are indistinguishable, making it impossible to carry out any analysis on the basis of citizenship. Nevertheless, the distinction between native and foreign labour can be easily introduced in the theoretical framework of this literature, as shown below.

\section{A Theoretical Model of Local Labour Markets with Foreign Workers}

The model developed in this section is based on the work of Blanchard and Katz (1992) but it departs from it because it explicitly models labour supplied by people with different nationalities. Labour can be supplied by either natives or foreigners from within (intra-EU) or outside the EU (extra-EU), who differ only with respect to their wage elasticity of labour supply. By assumption natives supply labour less elastically than foreigners as they may:

- have a more specific human capital than foreigners, or are more informed on available employment opportunities, that better meets the demand of local firms (e.g. Chiswick, 1978);

- have better access to unemployment benefits and social security than foreigners, or native workers may have been employed for a longer period of time than foreigners, so that foreign labour would be cheaper to hire when firms raise employment and vice-versa (e.g. Chiswick and Hurst, 1996).

- not maximise their income potential for the skills they possess as they may face higher marginal costs of migration than foreigners (e.g. Borjas, 2001).

There is some empirical evidence that immigrants supply labour more elastically than natives (e.g. Borjas, 20015.

The remaining features of Blanchard and Katz (1992) are unchanged. The model represents a world (the EU) composed of several regions, each producing a different bundle of goods under a constant returns to scale technology. Labour and firms are perfectly mobile across regions in the long run, and

\footnotetext{
5 e.g. Borjas (2001) estimates the relative labour supply elasticity of new immigrants relative to natives is 1.3.
} 
their mobility depends in part on the 'attractiveness' exerted by each region. Attractiveness is used in a very general sense and includes all those characteristics that make labour and firms willing to locate in a particular place. Hence, even with equal relative wages, regions can experience different net inflows of labourers and firms because of their specific attractiveness.

All variables in the model are measured relative to the EU average to identify regional labour demand shocks, which are modelled as deviation from EU trends. This approach has been used by the literature to capture remarkable empirical regularities in relative regional employment and unemployment in the EU (see Figures A.1 and A.2 in the Appendix, as well as Decressin and Fatas, 1995).

\section{Labour Demand}

As in Blanchard and Katz (1992), the labour demand in each region $i$ at time $t$ is:

$$
\mathrm{w}_{\mathrm{it}}=-\mathrm{d}\left(\mathrm{n}_{\mathrm{it}}-\mathrm{u}_{\mathrm{it}}\right)+\mathrm{z}_{\mathrm{it}}
$$

where $w_{i t}$ is the logarithm of region $i$ 's wage relative to the average wage across the EU. The parameter $n_{i t}$ is the logarithm of the regional labour force, which is composed of both natives and foreigners, relative to that at the EU level. The term $u_{i t}$ is region $i$ 's relative unemployment rate, which is defined as:

$$
\mathrm{u}_{\mathrm{it}}=\mathrm{U}_{\mathrm{it}} / \mathrm{E}_{\mathrm{it}}
$$

where $\mathrm{U}_{\mathrm{it}}$ and $\mathrm{E}_{\mathrm{it}}$ represent region $i$ 's total number of unemployed and employed (i.e. native plus foreigners), respectively, at time $t$. This definition of unemployment is useful so that the difference $\left(\mathrm{n}_{\mathrm{it}}\right.$ $-\mathrm{u}_{\mathrm{it}}$ ) in (3) is approximately equal to the logarithm of employment ${ }^{6}$. The coefficient $d$ is assumed to be positive.

The variable $z_{i t}$ denotes the relative number of firms in region $i$ and is defined as:

$$
z_{i t+1}-z_{i t}=-a w_{i t}+X_{i}^{d}+\varepsilon_{i t+1 \mid \Omega t}^{d}
$$

where $a$ is a positive parameter, $X^{d}{ }_{i}$ is the attractiveness of region $i$ to firms, which is assumed to be constant over time, and $\varepsilon_{i t+1}^{d}$ is a white noise stochastic process which represents unexpected changes in technology, the bundle of goods produced and their relative prices. The superscript $d$ of $\mathrm{X}^{\mathrm{d}}{ }_{\mathrm{i}}$ and $\varepsilon_{\text {it+1 }}^{\mathrm{d}}$ indicates 'demand', whilst $\Omega_{t}$ is the information set at time $t$. By assumption firms do not have different demands for native and foreign labour.

Since regions can differ in attractiveness to firms they can experience different rates of growth in relative labour demand. Labour demand movements are also stochastic: as long as regional wages are below their regional long-run equilibrium level firms will move in.

\footnotetext{
${ }^{6}$ If $\mathrm{U}, \mathrm{E}$ and $\mathrm{N}$ denote the numbers of unemployed, employed and those in the labour force, then $\mathrm{u}=\mathrm{U} / \mathrm{E} \approx \ln (1+\mathrm{U} / \mathrm{E})=\ln (\mathrm{N})$ $-\ln (\mathrm{E})$. Hence $(\mathrm{n}-\mathrm{u}) \approx \ln (\mathrm{N})-\ln (\mathrm{N})+\ln (\mathrm{E})=\ln (\mathrm{E})$.
} 


\section{Labour Supply}

A region's labour supply is obtained by adding up those of its native and foreign residents. For simplicity it is assumed that all nationalities can move freely across regions and member states ${ }^{\text {? }}$. Changes in native and foreign labour supply are formalised by:

$$
\begin{aligned}
& \Delta \mathrm{NL}_{\mathrm{it}}=\mathrm{b}_{1} \mathrm{~W}_{\mathrm{it}}+\mathrm{X}_{\mathrm{i}}^{\mathrm{s}}-\mathrm{gu}_{\mathrm{it}}+\varepsilon_{1 \mathrm{it}+1 \mid \Omega \mathrm{t}}^{\mathrm{s}} \\
& \Delta \mathrm{FL}_{\mathrm{it}}=\mathrm{b}_{2} \mathrm{~W}_{\mathrm{it}}+\mathrm{X}_{\mathrm{i}}^{\mathrm{s}}-\mathrm{gu}_{\mathrm{it}}+\varepsilon_{2 \mathrm{it}+1 \mid \Omega \mathrm{t}}^{\mathrm{s}}
\end{aligned}
$$

where $\Delta \mathrm{NL}_{\mathrm{it}}$ is the growth of the native labour force in region $i$ at time $t$, and $\Delta \mathrm{FL}_{\mathrm{it}}$ is the corresponding growth in the foreign labour force; $w_{i t}$ and $u_{i t}$ are defined as in (3); $b_{1}$ is the labour supply elasticity with respect to wages of natives, whilst $b_{2}$ is the corresponding measure for foreigners; $X_{i}^{s}$ denotes attractiveness to workers (e.g. local amenities), which is assumed to be identical for all citizens, and time-invariant. The coefficient $g$ denotes the sensitivity of native and foreign labour supply to region $i$ 's relative unemployment rate $e^{\square} \varepsilon_{i t+1}^{s}$ is a white noise stochastic component reflecting unexpected changes in labour supply, e.g. a change in migration laws. The superscript $s$ in $\mathrm{X}_{\mathrm{i}}^{\mathrm{s}}$ and in the error terms in (6a) and (6b) indicates 'supply'. By assumption $b_{2}$ is larger than $b_{1}$, implying that foreign citizens supply labour more elastically than natives.

The change in a region's relative labour force is the weighted average of that of its native and foreign residents, and it follows:

$$
\Delta \mathrm{n}_{\mathrm{it}}=\left(1-\theta_{\mathrm{it}}\right) \Delta \mathrm{NL}_{\mathrm{it}}+\theta_{\mathrm{it}} \Delta \mathrm{FL}_{\mathrm{it}}
$$

where $\theta_{\mathrm{it}}$ is the proportion of foreigners in region $i$ 's labour force at time $t$, which can only vary between zero and one (included). Short-term movements along the labour supply curves depend negatively on the relative wage and positively on the relative unemployment rate. For a given the level of attractiveness $\mathrm{X}_{\mathrm{i}}^{\mathrm{s}}$, as long as a region's relative wage is below its long-run level native and foreign labour out-migrate. Since workers and firms are assumed to be perfectly mobile in the long run there exists a stable structure of relative unemployment and wage differentials across regions even when employment growth rates differ across regions.

To close the model, the relative wage is assumed to be a function of unemployment ?

$$
\mathrm{w}_{\mathrm{it}}=-(1 / \mathrm{c}) \mathrm{u}_{\mathrm{it}}
$$

where $c$ is a positive parameter.

\footnotetext{
${ }^{7}$ Although the movements of extra-EU workers throughout member states are regulated (the elimination of the restrictions to free movements within the EU provided by the Single European Act of 1986 do not apply to extra-EU workers), they are not impossible.

${ }^{8}$ Allowing for different parameters for native and foreign labour groups does not modify the general prediction of the model, and results in a more complicated expression for the equilibrium conditions. Hence it is not discussed further.

${ }^{9}$ As mentioned in Fredriksson (1999), " this relationship is best thought of as relating the regional wage (in absolute terms) positively to the national wage rate, and negatively to the national and regional jobless rate respectively. Such a wage-setting schedule may result from national wage bargaining with additional wage drift at the firm level, given that the wage drift depends on labour market conditions in the particular region" (p.628). See also Blanchflower and Oswald (1994) for a discussion on the negative relationship between wages and the unemployment rate.
} 


\section{Equilibrium Paths and Steady States}

The equilibrium paths of region $i$ 's relative wage, unemployment rate, and labour force growth are derived from the intersection of relative labour demand and supply curves (the results are in the Appendix). Natives and foreigners face identical equilibrium paths with respect to the relative wage and the unemployment rate. These are respectively:

$$
\begin{aligned}
& \mathrm{w}^{*}{ }_{\mathrm{it}+1}=(1+\mathrm{dc})^{-1}\left[\left(1+\mathrm{dc}-\mathrm{d} \xi_{\mathrm{it}}-\mathrm{dcg}-\mathrm{a}\right) \mathrm{w}_{\mathrm{it}}+\mathrm{X}_{\mathrm{i}}^{\mathrm{d}}-\mathrm{d} X_{\mathrm{i}}^{\mathrm{s}}+\varepsilon^{\mathrm{d}} \mathrm{it+1}-\mathrm{d} \varepsilon^{\mathrm{s}}{ }_{\mathrm{it}+1 \mid \Omega \mathrm{t}}\right](9) \\
& \mathrm{u}^{*_{\mathrm{it}+1}}=(1+\mathrm{dc})^{-1}\left[\left(1+\mathrm{dc}-\mathrm{d} \xi_{\mathrm{it}}-\mathrm{dcg}-\mathrm{a}\right) \mathrm{u}_{\mathrm{it}}-\mathrm{c}\left(\mathrm{X}_{\mathrm{i}}^{\mathrm{d}}-\mathrm{d} X_{\mathrm{i}}^{\mathrm{s}}\right)-\mathrm{c}\left(\varepsilon_{\mathrm{it}+1 \mid \Omega \mathrm{t}}^{\mathrm{d}}-\mathrm{d} \varepsilon_{\mathrm{it}+1 \mid \Omega \mathrm{t}}^{\mathrm{s}}\right)\right]
\end{aligned}
$$

In equations (9) and (10) the term $\xi_{\mathrm{it}}$ is a shorthand for expression $\left(\left(1-\theta_{\mathrm{it}}\right) \mathrm{b}_{1}+\theta_{\mathrm{it}} \mathrm{b}_{2}\right)$, which increases with rising shares of foreigners in the labour force, i.e. $\partial \xi_{\mathrm{it}} / \partial \theta_{\mathrm{it}}>0$.

In contrast, natives and foreigners face different equilibrium paths with respect to the labour force growth, as they have different labour supply functions. In particular region $i$ 's native labour force changes according to:

$$
\begin{gathered}
\Delta \mathrm{NL}^{*}{ }_{\mathrm{it}+1}=(1+\mathrm{dc})^{-1}\left\{\left(1+\mathrm{dc}-\mathrm{d} \xi_{\mathrm{it}}-\mathrm{dcg}-\mathrm{a}\right) \Delta \mathrm{NL}_{\mathrm{it}}+\left(\mathrm{b}_{1}+\mathrm{gc}\right)\left(\mathrm{X}_{\mathrm{i}}^{\mathrm{d}}+\varepsilon_{\mathrm{it}+1 \mid \Omega \mathrm{t}}^{\mathrm{d}}\right)+\left(\mathrm{d} \xi_{\mathrm{it}}+\mathrm{a}-\mathrm{db} \mathrm{b}_{1}\right) \mathrm{X}_{\mathrm{i}}^{\mathrm{s}}\right. \\
\left.-\left(1+\mathrm{dc}-\mathrm{d} \xi_{\mathrm{it}}-\mathrm{a}+\mathrm{db}{ }_{1}\right) \varepsilon_{\mathrm{it}+1 \mid \Omega \mathrm{t}}^{\mathrm{s}}\right\}+\varepsilon_{\mathrm{it}+2 \mid \Omega \mathrm{t}}^{\mathrm{s}}
\end{gathered}
$$

By virtue of (4), the equilibrium path of native employment growth is approximately equal to the difference $\left(\Delta \mathrm{NL}_{\mathrm{it}+1}-\Delta \mathrm{u}_{\mathrm{it}+1}\right)$, i.e.:

$$
\begin{aligned}
\Delta \mathrm{NE}^{*}{ }_{\mathrm{it}+1}=(1+\mathrm{dc})^{-1}\left\{\left(1+\mathrm{dc}-\mathrm{d} \xi_{\mathrm{it}}-\mathrm{dcg}-\mathrm{a}\right) \Delta \mathrm{NE}_{\mathrm{it}}+\mathrm{d} \Delta \xi_{\mathrm{it}} \mathrm{u}_{\mathrm{it}-1}+\left(\mathrm{b}_{1}+\mathrm{gc}\right) \mathrm{X}_{\mathrm{i}}^{\mathrm{d}}+\left(\mathrm{d} \xi_{\mathrm{it}}+\mathrm{a}-\mathrm{db} \mathrm{b}_{1}\right) \mathrm{X}_{\mathrm{i}}^{\mathrm{s}}\right. \\
\left.+\left(\mathrm{b}_{1}+\mathrm{gc}+\mathrm{c}\right) \mathcal{\varepsilon}_{\mathrm{it}+1 \mid \Omega \mathrm{t}}^{\mathrm{d}}-\mathrm{cd} \varepsilon_{\mathrm{it} \mid \Omega \mathrm{t}}^{\mathrm{d}}-\left(1+2 \mathrm{dc}-\mathrm{d} \xi_{\mathrm{it}}-\mathrm{a}+\mathrm{db} \mathrm{b}_{1}\right) \varepsilon_{\mathrm{it}+1 \mid \Omega \mathrm{t}}^{\mathrm{s}}+\mathrm{cd} \varepsilon_{\mathrm{it} \mid \Omega \mathrm{t}}^{\mathrm{s}}\right\}+ \\
\varepsilon_{\mathrm{it}+2 \mid \Omega \mathrm{t}}^{\mathrm{s}}
\end{aligned}
$$

where NE stands for native employment. The equilibrium paths of native labour force and employment growths are unique in each region, though they can vary across them.

The steady states of region $i$ 's relative wage, unemployment rate, native labour force and employment growth are obtained by solving expressions (9), (10), (11) and (12) for the average values of each variable (see the Appendix). As in Blanchard-Katz (1992), the attractiveness of regions to workers and firms (i.e. $\mathrm{X}^{\mathrm{d}}{ }_{\mathrm{i}}$ and $\mathrm{X}_{\mathrm{i}}^{\mathrm{s}}$ ) are two underlying sources of regional employment growth. An increase in the attractiveness to workers reduces the regional relative wage and the growth rates of the local labour force and employment, whilst it increases the region's relative unemployment rate. An increase in attractiveness to firms increases the relative wage, the local labour force and employment and decreases the relative unemployment rate. However, in the model presented here there is a third source of employment growth: the share of foreigners in the local labour force. An increase in the proportion of foreigners in the region reduces the steady state levels of regional wages, native labour force and employment growth, whilst it raises the steady state of the unemployment rate, and vice-versa. 


\section{A One-off Shock to Labour Demand}

Similar to Blanchard and Katz (1992), the effect of a one-off shock in relative labour demand is transitory with respect to relative wage and unemployment but it is permanent on the level of relative native labour force, as the labour force level series is assumed to contain a unit root ${ }^{10}$. This assumption implies that any permanent change in the labour force results in an identical permanent change in the employment level. The effect of a labour demand shock on the growth of the native labour force and employment is therefore identical and it is equal to:

$$
\partial \Delta \mathrm{NL}_{\mathrm{it}+\mathrm{j}+1} / \partial \varepsilon_{\mathrm{it} \mid \Omega \mathrm{t}}^{\mathrm{d}}=\partial \Delta \mathrm{NE}_{\mathrm{it}+\mathrm{j}+1} / \partial \varepsilon_{\mathrm{it} \mid \Omega \mathrm{t}}^{\mathrm{d}}=\Sigma^{\infty}{ }_{\mathrm{j}=0} \lambda^{\mathrm{j}}\left[\left(\mathrm{b}_{1}+\mathrm{cg}\right) /(1+\mathrm{dc})\right]
$$

where $\lambda=\left(1+\mathrm{dc}-\mathrm{d} \xi_{\mathrm{it}}-\mathrm{dcg}-\mathrm{a}\right) /(1+\mathrm{dc})$. As $|\lambda|<1, \Sigma_{\mathrm{j}=0}^{\infty} \lambda^{\mathrm{j}} \rightarrow 0$ as $j \rightarrow \infty$, implying that the long run effect of a labour demand shock on both native labour force and employment growth is only temporary.

In contrast, the shock has a permanent effect on the level of native labour force and employment, as shown by:

$$
\begin{aligned}
& \partial \mathrm{NL}_{\mathrm{it}+\mathrm{j}+1} / \partial \varepsilon_{\mathrm{it} \mid \Omega \mathrm{t}}^{\mathrm{d}}=\partial \mathrm{NE}_{\mathrm{it}+\mathrm{j}+1} / \partial \varepsilon^{\mathrm{d}}{ }_{\mathrm{it} \mid \Omega \mathrm{t}}=(1-\lambda)^{-1} \Sigma^{\infty}{ }_{\mathrm{j}=0}\left\{1^{\mathrm{j}}\right\}-\lambda(1-\lambda)^{-1} \Sigma^{\infty}{ }_{\mathrm{j}=0}\left\{\lambda^{\mathrm{j}}\right\}\left[\left(\mathrm{b}_{1}+\mathrm{cg}\right) /\left(\mathrm{d} \xi_{\mathrm{it}}+\mathrm{dcg}\right.\right. \\
& +\mathrm{a})]
\end{aligned}
$$

Expression (14) tends to $\left(\mathrm{b}_{1}+\mathrm{cg}\right) /\left(\mathrm{d} \xi_{\mathrm{t}}+\mathrm{dcg}+\mathrm{a}\right) \neq 0$ as $j \rightarrow \infty$. In particular, since $\xi_{\mathrm{it}}$ is an increasing function of $\theta_{\text {it }}$, the long run effect of a shock on the native labour force and employment level is inversely related to the proportion of foreigners in region $i$ 's labour force. The higher the share of foreigners in the local labour force, the smaller the permanent effect of a labour demand shock on native labour and employment levels, and vice-versa. This result suggests that foreigners act as a 'cushion' to native employment, reducing its variability during the phases of the economic cycle. This hypothesis can be easily verified empirically by testing the sign of the coefficient $\mathrm{d} \xi_{\mathrm{it}} /(1+\mathrm{dc})$, which appears identically in equations (11) and (12).

\section{Methodology}

\subsection{Estimation Issues and Strategy Undertaken}

The empirical analysis focuses on the sign of $\mathrm{d} \xi_{\mathrm{it}} /(1+\mathrm{dc})$, which is estimated using equation (11) since it has a simpler structure than equation (12). Equation (11) can be re-written as the statistical model

\footnotetext{
${ }^{10}$ This assumption forces migration to explain permanent changes in employment level, and it is an important limitation as it may overestimate the role played by migration. Although this assumption is based on empirical findings for the US (Blanchard and Katz, 1992) and Europe (Decressin and Fatas, 1995), the Dickey-Fuller test on unit roots yields mixed results. The prior of a unit root in employment growth is rejected by over half of the sample (e.g. Decressin and Fatas, 1995; Fredriksson, 1999), but the prior is maintained on the basis of the low power of the test due to the short time series. However, when the model is modified to accommodate a stationary relative employment (Obstfeld and Peri, 1998), imposing the long-run effects of labour demand shocks on migration to be zero, "the first year effects and the response five years out are very close to those [of Blanchard and Katz (1992)]" (p.228). In this paper re-running the model on the series on employment level yields broadly similar results to those obtained when the series on employment growth. The Dickey-Fuller test is rejected by over half of the sample but the prior that the series contains a unit root is maintained on the basis of the low power of the test caused by the short time of the series (nine years).

${ }^{11}$ In particular: $\beta=(1+\mathrm{dc})^{-1}\left(1+\mathrm{dc}-\mathrm{dcg}-\mathrm{a}-\mathrm{db}_{1}\right) ; \gamma=(1+\mathrm{dc})^{-1} \mathrm{~d}\left(\mathrm{~b}_{1}-\mathrm{b}_{2}\right) ; \delta=(1+\mathrm{dc})^{-1}\left(\mathrm{~b}_{1}+\mathrm{gc}\right) ; \mu=\mathrm{a}(1+\mathrm{dc})^{-1} ; \chi=(1+$ $\mathrm{dc})^{-1} \mathrm{~d}\left(\mathrm{~b}_{2}-\mathrm{b}_{1}\right) \mathrm{X}_{\mathrm{i}}^{\mathrm{s}}$; and $v_{\mathrm{it}}$ is an error term that is assumed to be uncorrelated with present and past values of the explanatory
} 


$$
\Delta \mathrm{NL}^{*}{ }_{\mathrm{it}+1}=\beta \Delta \mathrm{NL}_{\mathrm{it}}+\gamma \theta_{\mathrm{it}} \Delta \mathrm{NL}_{\mathrm{it}}+\delta \mathrm{X}_{\mathrm{i}}^{\mathrm{d}}+\mu \mathrm{X}_{\mathrm{i}}^{\mathrm{s}}+\chi \theta_{\mathrm{it}}+v_{\mathrm{it}}
$$

Under the assumption that $b_{2}>b_{1}$, the coefficient $\gamma=(1+d c)^{-1} d\left(b_{1}-b_{2}\right)$ is negative, implying that the evolution of native labour force and employment are smoother in regions with higher proportions of foreigners in the local labour force, and vice-versa.

It is natural to think of estimating equation (15) with panel data techniques to exploit the longitudinal feature of the data, and to eliminate the likely presence of regional fixed unobserved variables. In doing so, one has to bear in mind that the variables $\mathrm{X}_{\mathrm{i}}^{\mathrm{d}}$ and $\mathrm{X}_{\mathrm{i}}^{\mathrm{s}}$, which were assumed to be regional timeinvariant constants, will also be eliminated in the estimation process 2

Since the lagged value of the dependent variable appears on the right hand side of (15), the explanatory variables are not all strictly exogenous. Hence, the estimation through fixed effects, random effects and first differencing will generally produce inconsistent estimates (e.g. Wooldridge, 1999). Inconsistency can be serious if the number of observational units is far larger than the fixed number of years for which data are available, as it is in this paper (Judson and Owen, 1999). Consistent estimates for equation (15) can however be obtained through a generalised method of moments procedure, where the explanatory variables are first transformed to eliminate unobservable regional fixed effects, and then estimated by instrumental variables. In particular this paper applies the dynamic panel data estimator developed by Arellano and Bond (1991), which instruments the endogenous variables with the lagged levels of dependent and predetermined variables and the differences of strictly exogenous variables. In the transformed equation, $\Delta \mathrm{NL}_{\mathrm{it}}$ is instrumented by its lagged values up to $\Delta \mathrm{NL}_{\mathrm{it}-2}$. This methodology relies on the testable assumption that the first difference of the residuals does not follow a second-order autocorrelation process (Wooldridge, 1999; Stata, 2001).

To obtain a labour force growth time series reflecting only labour demand shocks, the dependent variable in equation (15) is transformed using the method applied by Blanchard and Katz (1992) and the subsequent literature. This method assumes that any innovation in region $i$ 's relative labour force growth is a local labour demand shock. As a result, the dependent variable in equation (15) is 'purged' of EU disturbances by first estimating common movements across regions using:

$$
\Delta \log N_{i t}=\alpha_{i}+\beta_{i} \Delta \log N_{E U t}+\varphi_{i t}
$$

where $\mathrm{N}_{\mathrm{it}}$ is the number of natives in the labour force of region $i$ at time $t, \mathrm{~N}_{\mathrm{EUt}}$ is the corresponding EU average, and $\varphi_{i t}$ is an error term. Then the dependent variable is transformed into its regional relative equivalent by removing the common movements estimated from (16), using:

$$
\mathrm{NL}_{\mathrm{it}}=\log \mathrm{N}_{\mathrm{it}}-\beta_{\mathrm{i}} \log \mathrm{N}_{\mathrm{EUt}}
$$

where $\mathrm{N}_{\mathrm{it}}$ and $\mathrm{N}_{\mathrm{EUt}}$ are defined as in (16) and $\beta_{\mathrm{i}}$ is the estimate obtained from (16).

variables. This assumption is formally tested in the empirical analysis.

${ }^{12}$ As $\mathrm{X}_{\mathrm{i}}^{\mathrm{s}}$ is time-invariant, it was incorporated into the parameter $\chi\left(=-\gamma \mathrm{X}^{\mathrm{s}}\right)$ rather than being treated as an independent variable. 


\subsection{The Data}

Equation (15) is estimated on a panel consisting of 161 regions of 12 member states of the EU covering the period 1988-1997. The data are extracted from Eurostat's Labour Force Survey (LFS), a household survey that collects data on population stocks across the whole EU using internationally comparable definitions and methodology (see Eurostat, 1992). This feature makes the LFS an ideal data source for cross-country studies on international migration in the EU (e.g. Angrist and Kugler, 2001; Nahuis and Parikh, 2001).

The panel contains data on the regional stocks of labour by nationality as well as demographic and labour market data. The regions correspond to the administrative level immediately below that of the country (NUTS 2). The panel is unbalanced, and complete data are available for 128 regions $\frac{13}{\text {. }}$ Adjustments were made to maintain the geographic consistency of the sample as regional boundaries (and country boundaries in the case of Germany) have sometimes changed during the period $\frac{14}{4}$ Missing observations were filled in the case of Italy, where the nationality of the labour force for the years 19881991 was inferred from the aggregate data, using the average share of foreign labour during 1992-1997.

The employment data in the panel are restricted to employees aged 25 and above. Table 1 presents a statistical summary of the variables used in the empirical analysis, separating those that are explicitly modelled in equation (15) (dependent/independent) from those used as a control (control - labour market and control - demographics). Control variables refer mostly to natives to match the unit of measure of the dependent variable. Except for the share of foreigners in the labour force, the other variables used in the regression are transformed into their relative regional equivalent following the methodology applied in equations (16) and (17).

TAble 1 Summary STATISTICS OF VARIAbLeS USED

\begin{tabular}{|c|c|c|c|c|c|}
\hline Variable & Observations & Mean & STD & $\begin{array}{l}10^{\text {th }} \\
\text { Dec. }\end{array}$ & $\begin{array}{l}90^{\text {th }} \\
\text { Dec. }\end{array}$ \\
\hline \multicolumn{6}{|l|}{ Dependent/Independent } \\
\hline Labour Force Growth (natives) & 1,337 & .0121 & .0339 & -.024 & .049 \\
\hline Share of foreigners in the labour force & 1,337 & .0463 & .0458 & .002 & .125 \\
\hline \multicolumn{6}{|l|}{ Control-Labour market } \\
\hline Skilled/unskilled ratio (natives) & 1,326 & 2.328 & 1.064 & 1.34 & 4.18 \\
\hline Share of firms with $50+$ employees* & 945 & .3895 & .2001 & .001 & .518 \\
\hline Share of agricultural employment (natives)* & 945 & .0354 & .0603 & .011 & .120 \\
\hline \multicolumn{6}{|l|}{ Control-Demographics } \\
\hline Male/female ratio (natives) & 1,337 & 1.276 & .4179 & 1.07 & 2.00 \\
\hline
\end{tabular}


* = Data available only for the period 1992-1997.

The first row of Table 1 summarises the native labour force growth across the EU. There is significant variability across both time and regions: the period examined roughly covers an economic cycle, with regional employment levels in 1997 only slightly higher than in 1988, whilst the extreme values of the variable generally refer to less densely populated regions and islands 5 .

The statistics in the second row of Table 1 show that foreigners in the EU are a small percentage of the labour force compared with other OECD countries (e.g. OECD, 2000a,b). Foreign citizens are nil in several regions of the sample traditionally experienced positive net immigration rates (Germany, France, Benelux, and Denmark). The data indicate that foreigners in the EU are mainly non-recent immigrants, as the proportion of those with 10 or more years of residence in the host country 7 is well over $50 \%$. There is significant regional variation is the value of this ratio, which is lowest in regions that have experienced net immigration rates only since the 1980s (Spain, Italy, Greece, Portugal, and Ireland) and highest in traditional destination countries.

The control variables aim at capturing labour market and demographic characteristics. Among the former, the ratio of skilled/unskilled native labour is constructed using the aggregation of occupations suggested by Keesing (1966). Some control variables are available only since 1992, following a substantial restructuring and extension of the LFS questionnaire. Despite this administrative change, the Chow test on structural break on the data used in the empirical analysis is rejected, suggesting that the pre- and post-1992 series are comparable. Year dummy variables are included in the estimation to control for possible annual measurement errors in the LFS (e.g. national biases in data collection), though the results are unaffected when the year dummies are omitted.

\footnotetext{
15 e.g. Valle d'Aosta, Marche (Italy), Poitou-Charentes, Languedoc, Auvergne, Corsica (France), Western Macedonia, Aegean Islands, Crete, Peloponnisos (Greece), Ceuta and Melilla (Spain), Alentejo, Algarve (Portugal), Mid-West, North East (Ireland).

${ }^{16}$ This occurs as the LFS data capture mainly legal labour. Foreign immigrants are likely to be under-represented in the LFS as it is a household-based survey, which excludes many types of accommodation where foreign immigrants are likely to live (e.g. hostels). See Hogarth, Salt, and Singleton (1994) for a comprehensive discussion of issues related to measuring immigration in the EU.

${ }^{17}$ The mean value of this variable is $56.4 \%$ and its standard deviation is $15.37 \%$. Although there are 757 observations for which this variable is available in the sample, it is excluded from the estimation of equation (15) as it is not available for all countries throughout the period examined (e.g. it is available for Germany only for 1992).
} 


\section{$5 \quad$ Results}

Table 2 reports the regression results. The top half of the Table presents the estimates of the parameters of interest whilst the bottom half shows the result of post-estimation statistical tests. These include the overall significance of the regression coefficients (Wald statistic), model specification and validity of the over-identifying restrictions (Sargan test $\frac{18}{4}$ ) and structure of the error term. The sign ** highlights estimates that are statistically significantly different from zero as well as rejected outcomes of statistical tests. As shown in Table 2, all estimates are obtained from statistically significant regressions in which the error term does not follow an $\operatorname{AR}(2)$ process. The estimates reported are obtained from robust estimation to control for cross-regional heteroskedasticity. Following the recommendation of Arellano and Bond (1991), inference on the coefficients is based on the one-step dynamic panel data estimator, whilst inference on model specification uses the two-step estimator (see Stata, 2001). As a result, Table 2 reports the one-step coefficient estimates and standard errors but the two-step outcome of the Sargan test. Only the control variables available for the whole period 1989-1997 are included in the estimates shown in Table 2 whilst those obtained from the full set of control variables are reported in Table A.1 in the Appendix. All control variables are treated as predetermined as this strategy yields higher p-values of the Sargan test relative to when the controls are treated as strictly exogenous.

\footnotetext{
${ }^{18}$ The null hypothesis of the Sargan test postulates that the over-identifying restrictions are not valid (i.e. the instruments of the endogenous variables are correlated with the error term), hence the model is not properly specified.
} 
TABLE 2 REgRESSION RESULTS, 1989-1997

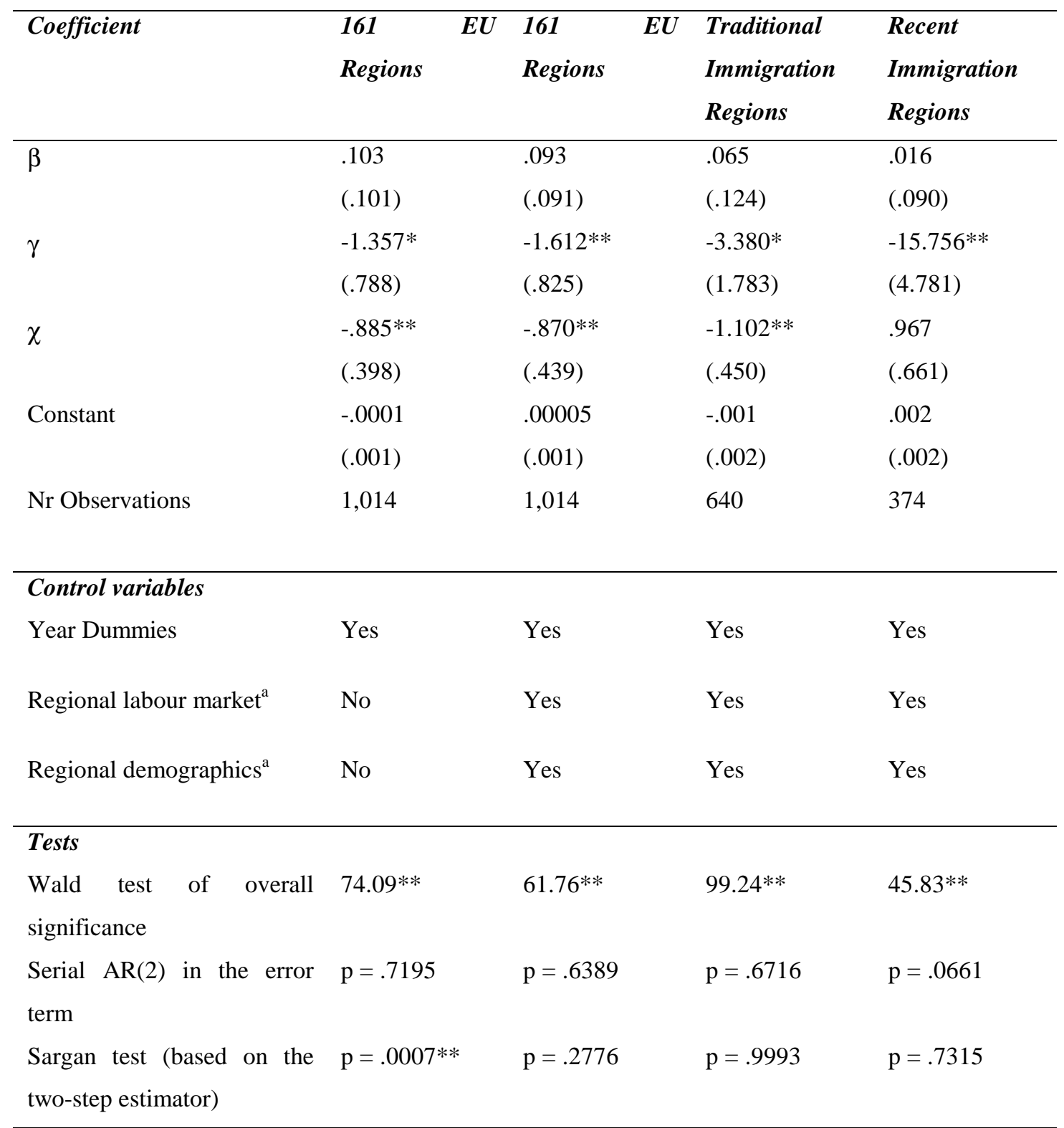

${ }^{a}=$ includes only the control variables available for the whole period 1989-1997.

The first and second columns in Table 2 report the results when equation (15) is estimated without and with control variables, respectively. The discussion focuses on the results shown in the second column, as the regression is better specified when control variables are included, as show by the Sargan test, which fails to be rejected.

The estimates obtained show that $\gamma$ has a negative sign and is statistically significant, suggesting that annual changes in a region's native employment are inversely related to the proportion of foreign citizens in that region's labour force. In particular, following a labour demand shock, the higher is the share of foreign labour the more foreigners absorb the year-after effects caused by the shock, cushioning natives from its full impact. Over time the shield provided by foreign labour makes native employment levels less variable, as predicted by the theoretical model presented in Section 3 . The 
negative sign of the coefficient $\gamma$ is robust to model specification, and to estimation on subsets of the panel, including the sub-periods prior and after 1992.

The magnitude of the cushioning effect is not insignificant. Foreign labour mitigates native employment from the effects of a shock well above its share in the local labour force. Using the estimate of $\gamma=1.612$ (second row, second column), foreigners are predicted to reduce the variability of native labour in a region by more than $8 \%$ when they constitute $5 \%$ of that region's labour force.

This result varies across countries. In member states that have traditionally imported foreign labour, the coefficient $\gamma$ is negative but seldom statistically significant. The parameter $\gamma$ is statistically significant only at the $10 \%$ level when equation (15) is estimated on the pooled regions of traditional immigration countries $^{19}$ (third column in Table 2). Perhaps this outcome is not surprising. During the reconstruction years that followed WWII until the early 1970s, most of these countries have systematically imported foreigners to fill gaps in their native labour force, most notably in Germany (Böhning, 1984 and 1991; Zimmermann, 1995). Between the mid-1970s and the late 1980s immigration came to a halt (except for family reunification), whilst the recent upsurge includes many asylum seekers and refugees whom cannot immediately enter the host country's labour force. A significant shielding effect would almost contradict these countries' past immigration policies.

In contrast, in member states that have experienced net immigration rates only recently (Greece, Italy, Spain, Portugal and Ireland), the term $\gamma$ is always statistically significant and its magnitude is very large. As shown in the fourth column of Table 2, the size of the coefficient $\gamma$ in recent immigration areas is a multiple of that reported in traditional immigration areas. This result may be due to the low incidence of foreigners in the local labour force of these regions (less than 1\%). An alternative explanation is that foreigners in recent immigration regions are 'newer' and may have a higher elasticity to supply labour than immigrants in traditional host countries. On the basis of the information available in the panel, this hypothesis is supported 20 , though one should ideally investigate it using microeconomic data.

To further assess the results presented in Table 2, a simple calculation was performed whereby the average composition of the labour force stock by nationality was compared with that of its changes over the period 1988-1997ㄹ. If foreigners shield native labour then they should be over-represented in the measure of the changes relative to that of the stocks. The top half of Table 3 shows the results of this calculation with respect to the labour force, whilst the bottom half of the Table shows the analogous calculation performed on employment data.

\footnotetext{
19 This result is mainly due to the presence of French and Dutch regions. When these are excluded from the regression (or when the agricultural employment share control variable is included), the coefficient $\gamma$ is still negative but no longer statistically significantly different from zero.

${ }^{20}$ The average proportion of foreigners residing 10 or more years in the host country is $40 \%$ in Recent Immigration Regions visà-vis $62 \%$ in Traditional Immigration Regions.

${ }^{21}$ I.e. $\Sigma_{\mathrm{it}} \mathrm{LF}_{\mathrm{it}, \text { foreign }} / \Sigma_{\mathrm{it}} \mathrm{LF}_{\mathrm{it} \text {, (natives + foreigners) }}$ is compared to $\Sigma_{\mathrm{it}} \Delta \mathrm{LF}_{\mathrm{it}, \text { foreign }} / \Sigma_{\mathrm{it}} \Delta \mathrm{LF}_{\mathrm{it} \text {, (natives + foreigners) }}$
} 


\begin{tabular}{|c|c|c|c|c|c|c|}
\hline & \multicolumn{2}{|c|}{ Pooled Regions } & \multicolumn{2}{|c|}{$\begin{array}{l}\text { Traditional } \\
\text { Immigration Regions }\end{array}$} & \multicolumn{2}{|c|}{$\begin{array}{l}\text { Recent Immigration } \\
\text { Regions }\end{array}$} \\
\hline & Stock & Change & Stock & Change & Stock & Change \\
\hline \multicolumn{7}{|l|}{ LABOUR FORCE } \\
\hline Foreigners & $4.63 \%$ & $5.54 \%$ & $6.75 \%$ & $6.79 \%$ & $0.75 \%$ & $2.32 \%$ \\
\hline Natives & 95.37 & 94.46 & 93.25 & 93.21 & 99.25 & 97.68 \\
\hline \multicolumn{7}{|l|}{ EMPLOYMENT } \\
\hline Foreigners & 4.54 & 3.91 & 6.20 & 4.06 & 0.70 & 3.13 \\
\hline Natives & 95.46 & 96.09 & 93.80 & 95.94 & 99.30 & 96.87 \\
\hline Number of Cases & 1,519 & 1,351 & 893 & 800 & 626 & 551 \\
\hline
\end{tabular}

The measure in the top left corner of Table 3 ('Pooled Regions - stock') shows that during 1988-1997 foreigners were on average $4.63 \%$ of the labour force stock across the EU but constituted $5.54 \%$ of its changes ('Pooled Regions - Change'), implying that foreigners shield native labour during the economic cycle. This outcome is only marginally supported in traditional immigration regions (columns in the middle of Table 3), whilst it is remarkably strong in recent immigration regions, providing additional support to the regression results discussed earlier.

With respect to employment, foreigners do not appear to cushion native jobs overall (bottom half of the first column), as they constitute $4.54 \%$ of the regional employment stock but only $3.91 \%$ of its changes. Foreigners are particularly under-represented in the measures of the employment change in traditional immigration regions, which have traditionally experienced demand-driven immigration, whilst they seem to shield native labour in recent immigration regions, as already emerged in the regression results.

\section{Conclusions}

This paper shows that when foreigners have a higher wage elasticity to supply labour than natives, they can reduce the variability of native labour growth and level as they absorb some of the impact of a labour demand shock. The empirical results, based on macroeconomic data covering $161 \mathrm{EU}$ regions during 1988-1997, support this hypothesis. 


\section{References}

Angrist, J.D. and Kugler, A.D. (2001) Immigration, Native Employment, and Labor Market Flexibility in Western Europe (mimeo). Cambridge, MA: MIT Press.

Arellano, M. and Bond, S.R. (1991) 'Some Specification tests for Panel Data: Monte Carlo Evidence and an Application to Employment Equations', Review of Economic Studies 58: 277-298.

Bartik, T.J. (1993) 'Who Benefits from Local Job Growth: Migrants or the Original Residents?', Regional Studies 27(4): 297-311.

Blanchard, O.J. and Katz, L.F. (1992) 'Regional Evolutions', Brookings Papers on Economic Activity $0(1): 1-75$.

Blanchflower, D.G. and Oswald, A.J. (1994) The Wage Curve, Cambridge, MA: MIT Press.

Böhning, W.R. (1984) Studies in International Labour Migration, London: Macmillan.

Böhning, W.R. (1991) 'Integration and Immigration Pressures in Western Europe'. International Labour Review 130(4): 445-458.

Borjas, G.J. (2001) 'Does Immigration Grease the Wheels of the Labor Market?', Brookings Papers on Economic Activity 0(1): 69-119.

Chiswick, B.R. (1978) 'The Effect of Americanization on the Earnings of Foreign-Born Men', Journal of Political Economy 86(5): 867-921.

Chiswick, B.R. and Hurst, M.E. (1996) 'The Employment, Unemployment and Unemployment Compensation Benefits of Immigrants', Paper presented at the European Science Foundation Conference on Migration and Development Policy, France, June.

Decressin, J. and Fatas, A. (1995) 'Regional Labour Market Dynamics in Europe', European Economic Review 39: 627-1655.

De New, J.P. and Zimmermann, K.F. (1994) 'Native Wage Impacts of Foreign Labor: A Random Effects Panel Analysis', Journal of Population Economics 7(2): 177-192.

Dolado, J.J., Jimeno, J.F., and Duce, R. (1996) The Effects of Migration on the Relative Demand of Skilled versus Unskilled Labour: Evidence from Spain, Centre for Economic Policy Research Discussion Paper 1476, London. 
Eurostat (1992) Labour Force Survey: Methodology and Definitions, Luxembourg: Eurostat.

Fredriksson, P. (1999) 'The Dynamics of Regional Labor Markets and Active Labor Market Policy: Swedish Evidence', Oxford Economic Papers 51(4): 623-648.

Gavosto, A., Venturini, A. and Villosio, C. (1999) 'Do Immigrants Compete with Natives?', Labour 13(3): 603-622.

Hogarth, J., Salt, J., and Singleton, A. (1994) Europe's International Migrants. Data Sources, Patterns and Trends, London: HMSO.

Jimeno, J.F. and Bentolila, S. (1998) 'Regional Unemployment Persistence (Spain, 1976-1994)', Labour Economics 5(1): 25-51.

Judson, R.A. and A. L. Owen (1999) 'Estimating Dynamic Panel Data Models: A Guide for Macroeconomists', Economics Letters 65: 9-15.

Keesing, D.B. (1966) 'Labor Skills and Comparative Advantage', American Economic Review 56(2): 249-258.

Layard, R. et al. (1992) East-West Migration: the Alternatives, Cambridge, MA: MIT Press.

Nahuis, R. and Parikh, A. (2001) 'Factor Mobility and Regional Disparities: East, West, Home's Best?', Paper presented at the Economics Program Seminars, Research School of Social Sciences, Canberra: Australian National University, $27^{\text {th }}$ April.

Obstfeld, M. and Peri, G. (1998) 'Regional non-adjustment and Fiscal Policy', Economic Policy: A European Forum 0(26): 205-247.

Organisation for Economic Co-operation and Development (OECD) (2000a), Employment Outlook 68, Paris: OECD.

Organisation for Economic Co-operation and Development (OECD) (2000b) SOPEMI Report, Paris: OECD.

Pischke, J.S. and Veilling, J. (1996) 'Employment Effects of Immigration to Germany: An Analysis Based on Local Labor Markets', Review of Economics and Statistics 79(4): 594-604.

Simon, J.L. (1989) The Economic Consequences of Immigration, Oxford: Basil Blackwell in association with The Cato Institute. 
Stata Corporation (2001) Stata Statistical Software: Release 7.0, College Station, TX: Stata Corporation.

Wooldridge, J.M. (1999) Econometric Analysis of Cross Section and Panel Data, Cambridge, MA: The MIT Press.

Zimmermann, K.F. (1995) 'European Migration: Push and Pull' in M. Bruno and B. Pleskovic (Eds.), Supplement to the World Bank Economic Review and the World Bank Research Observer, Washington, DC: The World Bank.

*** (2003) 'Have Europeans Become More Mobile? A Note on Regional Evolutions in the EU: 19881997', Economics Letters (forthcoming). 
Appendix

Figure A.1 Relative Employment Growth IN THE Regions of The European Union, 1988-1997

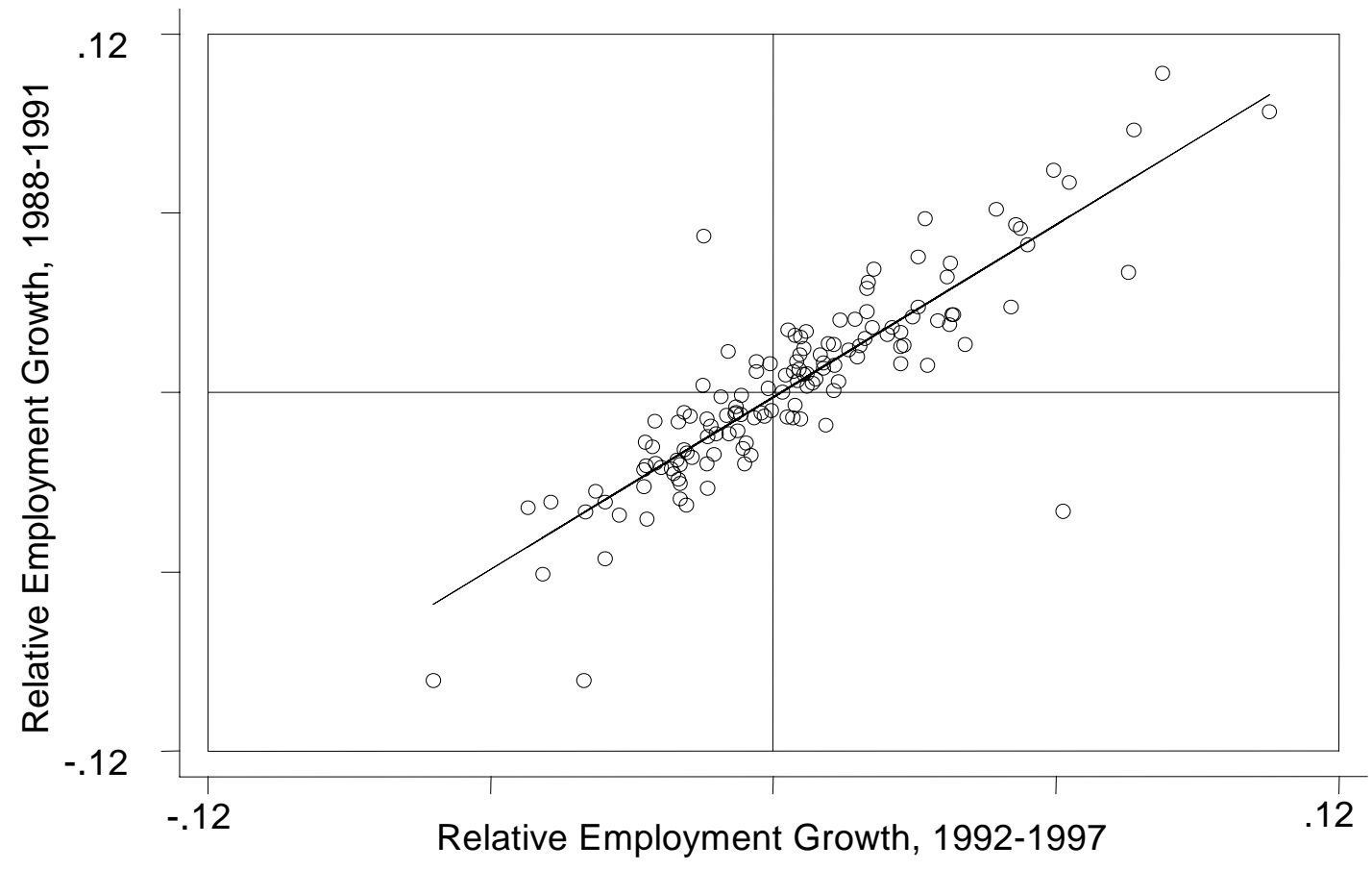

Figure A.2 UNEMPLOYMENT RATES IN THE REgiONS OF THE EUROPEAN UNION, 1988-1997

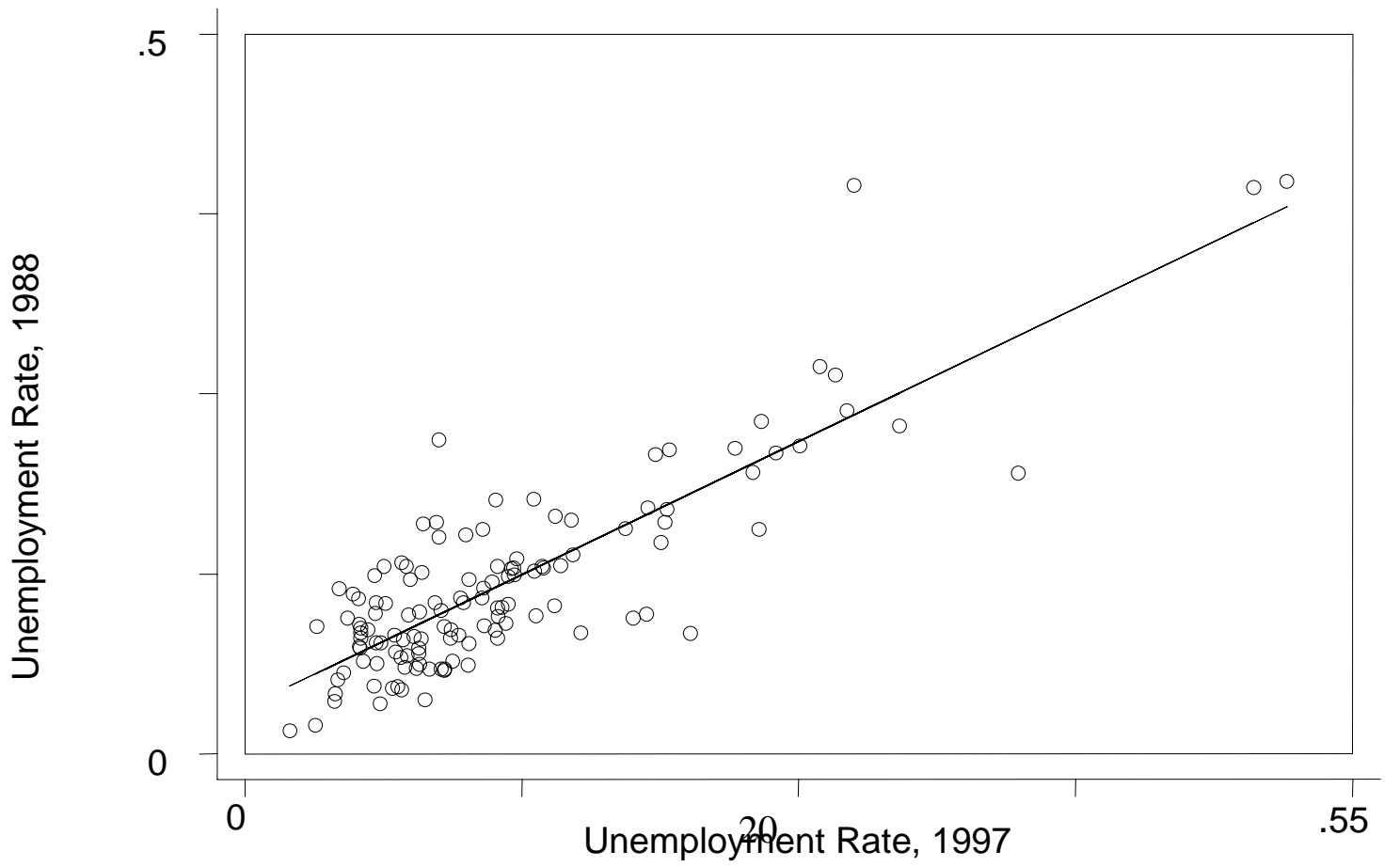




\section{A Brief Summary OF THE TheOretical Model}

\section{Solving the Model}

Substituting expressions (6a), (6b) and (8) in (7) yields:

$$
\Delta \mathrm{n}_{\mathrm{it}}=\left[\left(1-\theta_{\mathrm{it}}\right) \mathrm{b}_{1}+\theta_{\mathrm{it}} \mathrm{b}_{2}+\mathrm{cg}\right] \mathrm{w}_{\mathrm{it}}+\mathrm{X}_{\mathrm{si}}+\varepsilon_{\mathrm{it}+1 \mid \Omega \mathrm{t}}^{\mathrm{s}}
$$

whilst substituting expressions (A.1) and (5) in (3) yields:

$$
\left.(1+\mathrm{dc}) \Delta \mathrm{w}_{\mathrm{it}}=\left[1+\mathrm{dc}-\mathrm{d} \xi_{\mathrm{it}}-\mathrm{dcg}-\mathrm{a}\right] \mathrm{w}_{\mathrm{it}}-\mathrm{dX} \mathrm{X}_{\mathrm{si}}+\mathrm{X}_{\mathrm{di}}-\mathrm{d} \varepsilon^{\mathrm{s}}{ }_{\mathrm{it}+1 \mid \Omega \mathrm{t}}+\varepsilon_{\mathrm{it}+1 \mid \Omega \mathrm{t}}^{\mathrm{d}}\right]
$$

In equilibrium, relative labour supply and demand are equal. This yields the restricted equation, consisting of a system that solves for relative wages and employment growth. The equilibrium paths for relative wage, unemployment, labour force and employment growth are:

$\mathrm{w}^{*}{ }_{\mathrm{it}+1}=(1+\mathrm{dc})^{-1}\left[\left(1+\mathrm{dc}-\mathrm{d} \xi_{\mathrm{it}}-\mathrm{dcg}-\mathrm{a}\right) \mathrm{w}_{\mathrm{it}}+\mathrm{X}_{\mathrm{i}}^{\mathrm{d}}-\mathrm{d} \mathrm{X}_{\mathrm{i}}^{\mathrm{s}}+\varepsilon^{\mathrm{d}}{ }_{\mathrm{it}+1 \mid \Omega \mathrm{t}}-\mathrm{d} \varepsilon^{\mathrm{s}}{ }_{\mathrm{it}+1 \mid \Omega \mathrm{t}}\right](\mathrm{A} .3 \mathrm{a})$

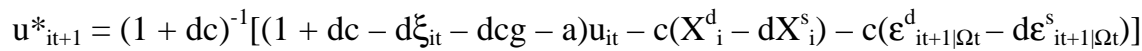

$$
\begin{aligned}
\Delta \mathrm{n}_{\mathrm{it}+1}= & {\left[(1+\mathrm{dc})\left(\xi_{\mathrm{it}}+\mathrm{cg}\right)\right]^{-1}\left[\left(\xi_{\mathrm{it}+1}+\mathrm{cg}\right)\left(1+\mathrm{dc}-\mathrm{d} \xi_{\mathrm{it}}-\mathrm{dcg}-\mathrm{a}\right)\right] \Delta \mathrm{n}_{\mathrm{it}}+(1+\mathrm{dc})^{-1}\left(\xi_{\mathrm{it}+1}+\mathrm{cg}\right)\left(\mathrm{X}_{\mathrm{i}}^{\mathrm{d}}+\right.} \\
& \left.\varepsilon_{\mathrm{it}+1 \mid \Omega \mathrm{t}}^{\mathrm{d}}\right)+\left[(1+\mathrm{dc})\left(\xi_{\mathrm{it}}+\mathrm{cg}\right)\right]^{-1}\left[(1+\mathrm{dc})\left(\xi_{\mathrm{it}}+\mathrm{cg}\right)+\left(\xi_{\mathrm{it}+1}+\mathrm{cg}\right)(\mathrm{a}-1-\mathrm{dc})\right] \mathrm{X}_{\mathrm{i}}^{\mathrm{s}}+\left[( 1 + \mathrm { dc } ) \left(\xi_{\mathrm{it}}+\right.\right. \\
& \mathrm{cg})]^{-1}\left[\left(\xi_{\mathrm{it}+1}+\mathrm{cg}\right)(\mathrm{a}-1-\mathrm{dc})\right] \varepsilon_{\mathrm{it}+1}^{\mathrm{s}}+\varepsilon_{\mathrm{it}+2 \mid \Omega \mathrm{t}}^{\mathrm{s}}
\end{aligned}
$$

Solving (A.3a) and (A.3b) with respect to wages yields:

$$
\mathrm{w}_{\mathrm{it}+\mathrm{j}+1}=\Sigma^{\infty}{ }_{\mathrm{j}=0}\left[\left(1+\mathrm{dc}-\mathrm{d} \xi_{\mathrm{it}}-\mathrm{dcg}-\mathrm{a}\right) /(1+\mathrm{dc})\right]^{\mathrm{j}} *(1+\mathrm{dc})^{-1}\left[\mathrm{X}_{\mathrm{di}}-\mathrm{d} \mathrm{X}_{\mathrm{si}}-\mathrm{d} \varepsilon^{\mathrm{s}}{ }_{\mathrm{it}+1 \mid \Omega \mathrm{t}}+\varepsilon^{\mathrm{d}}{ }_{\mathrm{it}+1 \mid \Omega \mathrm{t}}\right]
$$

The effect of a shock on wages is:

$$
\partial \mathrm{w}_{\mathrm{it}+\mathrm{j}+1} / \partial \varepsilon_{\mathrm{it} \mid \Omega \mathrm{t}}^{\mathrm{d}}=\left[\left(1+\mathrm{dc}-\mathrm{d} \xi_{\mathrm{it}}-\mathrm{dcg}-\mathrm{a}\right) /(1+\mathrm{dc})\right]^{\mathrm{j}}(1+\mathrm{dc})^{-1}
$$

which tends to zero as $\mathrm{j} \rightarrow \infty$ because the term inside the square bracket is smaller than one.

The effect of a shock on the unemployment rate is $\partial \mathrm{u}_{\mathrm{it}+\mathrm{j}} / \partial \varepsilon^{\mathrm{d}}{ }_{\mathrm{it}+1 \mid \Omega \mathrm{t}}=-\mathrm{c} \partial \mathrm{w}_{\mathrm{it}+\mathrm{j}+1} / \partial \varepsilon^{\mathrm{d}}{ }_{\mathrm{it} \mid \Omega \mathrm{t}}$ which also tends to zero as $\mathrm{j} \rightarrow \infty$.

The effect of a shock on the aggregate labour force (hence employment) growth is:

$$
\partial \Delta \mathrm{n}_{\mathrm{it}+\mathrm{j}+1} / \partial \varepsilon_{\mathrm{it} \mid \Omega \mathrm{t}}^{\mathrm{d}}=\left(\left(1-\theta_{\mathrm{it}+1}\right) \mathrm{b}_{1}+\theta_{\mathrm{it}+1} \mathrm{~b}_{2}+\mathrm{cg}\right) \partial \mathrm{w}_{\mathrm{it}+\mathrm{j}+1} / \partial \varepsilon_{\mathrm{it} \mid \Omega \mathrm{t}}^{\mathrm{d}}
$$

which also tends to zero as $\mathrm{j} \rightarrow \infty$. However, the level of aggregate employment is permanently affected as:

$$
\partial \mathrm{n}_{\mathrm{it}+\mathrm{j}+1} / \partial \varepsilon^{\mathrm{d} t \mid \Omega \mathrm{t}}=\left[\left(\xi_{\mathrm{it}}+\mathrm{cg}\right)\left(\xi_{\mathrm{it}+1}+\mathrm{cg}\right)\right] /\left[\left(\xi_{\mathrm{it}}-\xi_{\mathrm{it}+1}\right)(1+\mathrm{dc})+\left(\xi_{\mathrm{it}+1}+\mathrm{cg}\right)\left(\mathrm{d} \xi_{\mathrm{it}}+\mathrm{dcg}+\mathrm{a}\right)\right] \neq 0
$$


In particular:

$$
\begin{aligned}
& \partial \mathrm{NL}_{\mathrm{it}+\mathrm{j}+1} / \partial \varepsilon_{\mathrm{it} \mid \Omega \mathrm{t}}^{\mathrm{d}}=\left(\mathrm{b}_{1}+\mathrm{cg}\right) /\left[\mathrm{d} \xi_{\mathrm{it}}+\mathrm{dcg}+\mathrm{a}\right] \\
& \partial \mathrm{FL}_{\mathrm{it}+\mathrm{j}+1} / \partial \varepsilon_{\mathrm{it} \mid \Omega \mathrm{i}}^{\mathrm{d}}=\left(\mathrm{b}_{2}+\mathrm{cg}\right) /\left[\mathrm{d} \xi_{\mathrm{it}}+\mathrm{dcg}+\mathrm{a}\right]
\end{aligned}
$$

The steady states of the relative wage, employment growth and unemployment rate for region $i$ are obtained by solving equations (A.3a), (A.3b) and (A.3c) for the average values of these variables. For the natives, these steady states are respectively:

$$
\begin{aligned}
& \underline{\mathrm{w}_{\mathrm{i}}}=\left(\mathrm{a}+\mathrm{d} \xi_{\mathrm{it}}+\mathrm{dcg}\right)^{-1}\left(\mathrm{X}_{\mathrm{i}}^{\mathrm{d}}-\mathrm{d} \mathrm{X}_{\mathrm{i}}^{\mathrm{s}}\right) \\
& \underline{\Delta \mathrm{NL}_{\mathrm{i}}}=\left(\mathrm{a}+\mathrm{d} \xi_{\mathrm{it}}+\mathrm{dcg}\right)^{-1}\left[\left(\mathrm{~b}_{1}+\mathrm{cg}\right) \mathrm{X}_{\mathrm{i}}^{\mathrm{d}}+\left(\mathrm{a}+\mathrm{d} \xi_{\mathrm{it}}-\mathrm{db}_{1}\right) \mathrm{X}_{\mathrm{i}}^{\mathrm{s}}\right] \\
& \underline{\mathrm{u}_{\mathrm{i}}}=\left(\mathrm{a}+\mathrm{d} \xi_{\mathrm{it}}+\mathrm{dcg}\right)^{-1}\left[-\mathrm{c}\left(\mathrm{X}_{\mathrm{i}}^{\mathrm{d}}-\mathrm{d} \mathrm{X}_{\mathrm{i}}^{\mathrm{s}}\right)\right]
\end{aligned}
$$

Foreign labour raises $\xi_{\mathrm{it}}$ and therefore reduces the steady state level of relative wages and relative labour force and employment growth, but it raises that of relative unemployment.

\section{Preliminary Tests of the Data}

\section{Tests on the Construction Region-Specific Variables}

The OLS regression on (16) on employment by nationality indicates that on average less than a quarter of yearly movements in labour force are common to all regions. In each case, a Chow test has been performed to test the possibility of structural break in the data pre- and post-1992. The test failed to reject the hypothesis of structural change between these two periods. In several instances, the regression by region failed the F-test of overall significance. These cases yielded both insignificant estimates of $\beta_{\mathrm{i}}$ and significance of the regression, and are characterised by low or negative adjusted Rsquares. However, in virtually all cases, the RESET ${ }^{2}$ test of specification failed to reject the hypothesis that equation (16) has no omitted variables. The density estimation of $\alpha_{i}$ and $\beta_{i}$ across all regions show that both parameters have a distribution similar to a normal with mean values of 1.419 and 0.611 , respectively. Hence the assumption of normality and the properties of large samples can be applied in the estimation.

The cross-section regression (16) on all regions pooled together indicate the presence of heteroskedasticity, which is tested using the Cook-Weisberg test $\frac{23}{3}$ However, when the regression (16) is performed by region, the test fails to reject the null hypothesis of constant variance. Since the construction of the region-specific variables is based on the results obtained in the latter case, the issue of heteroskedasticity does not appear to be of concern.

\footnotetext{
22 If the functional form (16) is properly specified (i.e. there are no missing variables) then adding the fitted value of the dependent variable from (16) as an additional explanatory variable in an augmented version of (16) should not increase the significance of the model.

${ }^{23}$ This heteroskedasticity test models the variance of the error term in (16) as $\sigma^{2} \exp (\mathrm{zt})$ where $\mathrm{z}$ is a variable equal to the fitted values $X \beta$. The test is of $t=0$ (Stata, 2001).
} 
The leverage analysis 24 of the pooled regression indicates that in the case of employment growth the French region of Corsica is a clear outlier, whilst in the cases of unemployment rate the extremes are several Spanish, Portuguese, Greek and Italian regions. The models were re-estimated dropping these observations. Since similar results were obtained, all regions are left in the working sample.

${ }^{24}$ This analysis studies the graph of leverage (the weight of each observation in yielding the regression result) against the normalised residuals squared. This graph allows the researcher to identify observations which are outliers and have a significant impact on the regression results obtained, and it is used to better interpret the original data (Stata, 2001). 
TABLE A.1 Regression ReSUlts, 1993-1997

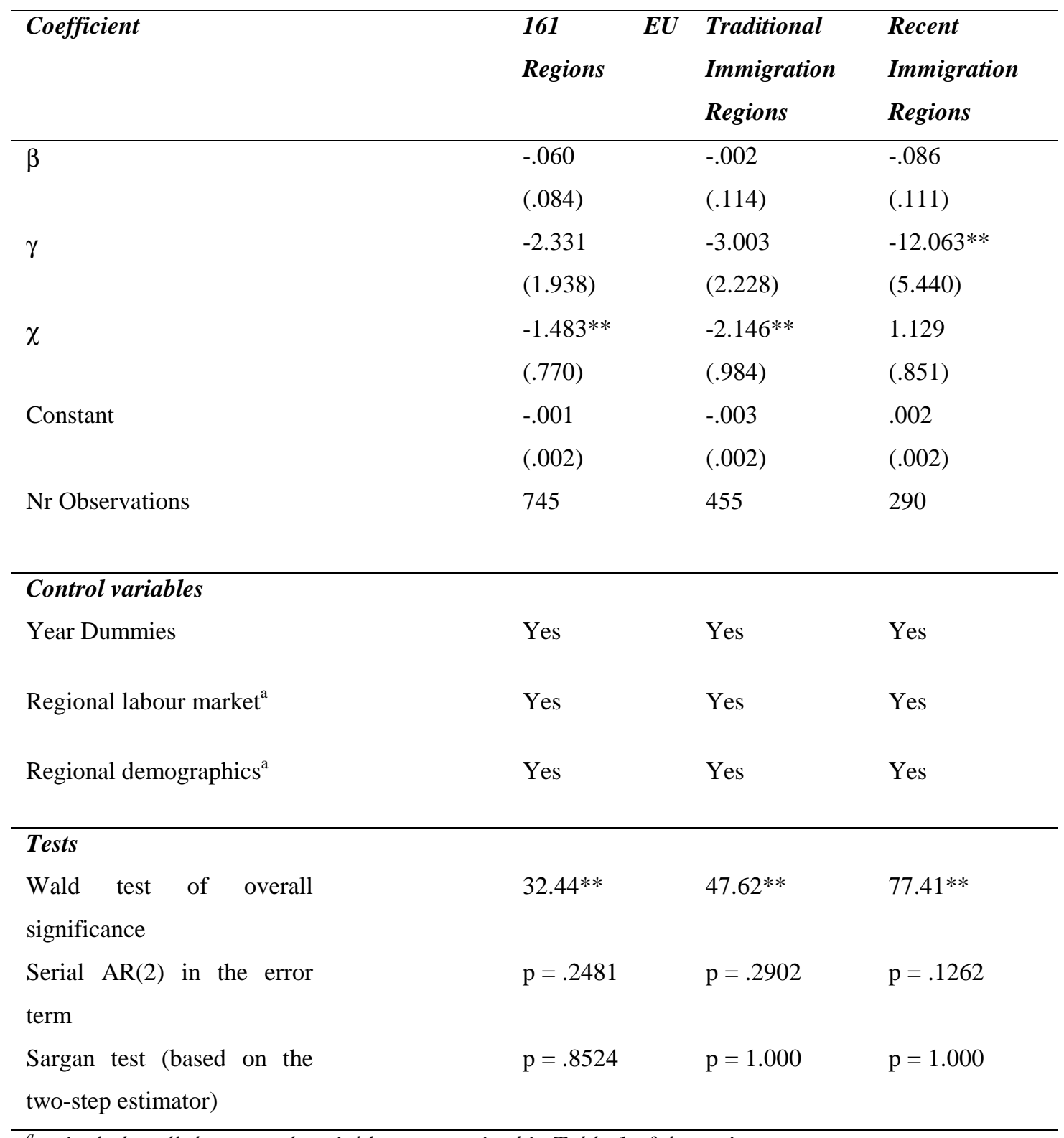

${ }^{a}=$ includes all the control variables summarised in Table 1 of the main text. 